\title{
Collembola (Arthropoda: Hexapoda) from the Arctic skua (Stercorarius parasiticus L.) habitat on the Nordaustlandet (Svalbard)
}

\section{Комлемболы (Arthropoda: Hexapoda) из местообитания короткохвостого поморника (Stercorarius parasiticus L.) на Северо-Восточной Земле (архипелаг Шпиџберген)}

\author{
N.V. Lebedeva ${ }^{1} \&$ A.A. Taskaeva ${ }^{2}$ \\ Н.В. Иебедева ${ }^{1}$, А.А. Таскаева ${ }^{2}$
}

\begin{abstract}
${ }^{1}$ Azov Branch, Murmansk Marine Biological Institute, Kola Scientific Center, Russian Academy of Sciences, Institute of Arid Zones, Southern Scientific Center, Russian Academy of Sciences, Chekhov, 41, Rostov on Don 344006, Russia. E-mail: lebedeva@ssc-ras.ru

${ }^{1}$ Азовский филиал Мурманского морского биологического института Кольского научного центра Российской академии наук, Институт Аридных зон Южного научного центра РАН, ул. Чехова, 41, г.Ростов-на-Дону 344006, Россия.

${ }^{2}$ Institute of Biology, Komi Scientific Center, Ural Department, Russian Academy of Sciences, Kommunisticheskaya, 28, Syktyvkar 167982, Russia. E-mail: taskaeva@ib.komisc.ru

${ }^{2}$ Институт биологии Коми научного центра Уральского отделения Российской академии наук, ул. Коммунистическая, 28, Сыктывкар 167982, Россия.
\end{abstract}

KEY WORDS: Collembola, Arctic skua, Stercorarius parasiticus, habitat, Svalbard archipelago, Nordaustlandet.

КЛЮЧЕВЫЕ СЛОВА: Коллемболы, местообитание, короткохвостый поморник, Stercorarius parasiticus, архипелаг Шпицберген, о. Северо-Восточная Земля.

ABSTRACT. For the first time data on springtails (Arthropoda: Hexapoda: Collembolla) from the Arctic skua (Stercorarius parasiticus L.) habitat were collected in the poorly investigated area of Svalbard archipelago (Nordaustlandet). Eight species of springtails were found in this habitat: Oligaphorura groenlandica (Tullberg, 1876), Ceratophysella longispina (Tullberg, 1876), Hypogastrura tullbergii (Schäffer, 1900), Anurida polaris (Hammer, 1954), Desoria tshernovi (Martynova, 1974), Folsomia binoculata (Wahlgren, 1899), Folsomia quadrioculata (Tullberg, 1871), and Sminthurides malmgreni (Tullberg, 1876). Hypogastrura tullbergii $(38.8 \%)$ and Desoria tshernovi $(26.8 \%)$ dominated in the sample.

РЕЗЮМЕ. Впервые собраны данные о коллеболах (Arthropoda: Hexapoda: Collembolla) из местообитания короткохвостого поморника (Stercorarius parasiticus L.) из малоизученного района архипелага Шпицберген (о-в Северо-Восточная Земля). В почвенно-растительном покрове обнаружено 8 видов ногохвосток: Oligaphorura groenlandica (Tullberg, 1876), Ceratophysella longispina (Tullberg, 1876), Hypogastrura tullbergii (Schäffer, 1900), Anurida polaris (Hammer, 1954), Desoria tshernovi (Martynova, 1974), Folsomia binoculata (Wahlgren, 1899), Folsomia quadrioculata (Tullberg, 1871) и Sminthurides malmgreni (Tullberg, 1876). В исследуемом образце доминировали Hypogastrura tullbergii $(38,8 \%)$ и Desoria tshernovi $(26,8 \%)$.

\section{Introduction}

Nordaustlandet is the northernmost and second largest $\left(14,443 \mathrm{~km}^{2}\right)$ island of Svalbard. Its surface is a plateau with a maximum height of about $700 \mathrm{~m}$ a.s.l. Glaciers, covering about $77 \%$ of the island, sometimes reach more than $500 \mathrm{~m}$ in thickness. The ice-free area of the Nordaustlandet belongs to the polar desert zone. The features of this zone are a harsh climate (heat deficit, the average temperature of the warmest month does not exceed $2^{\circ} \mathrm{C}$, the average annual temperature is $-8.2^{\circ} \mathrm{C}$ ), poor floristic composition, discontinuous and rarefied vegetation. Soils can be covered with snow and frozen for nine months a year. Vegetation is confined to the curtains, the cavities of microrelief, and microslopes of favorable exposure. Plant communities are primarily composed of bryophytes and lichen synusia. Vascular plants are subordinate in this habitat [Koroleva, 2007].

So far over 500 species of insects and soil invertebrates including 61 species collembolans (Collembola) or springtails were registered for the archipelago [Coulson, 2007]. Collembola may reach very high population densities up to 240,000 ind. $\times \mathrm{m}^{-2}$ in the rich moss communities under bird cliffs on Svalbard [Bengtson et al., 1974]. However, most of the specimens were collected on Spitsbergen, the largest island of Svalbard, around settlements and scientific stations. The other islands of the archipelago poorly investigated. The first information about the 12 species of collembolans from the 
Nordaustlandet was published in 1928 [Summerhayes \& Elton, 1928]. Later, when it was screened, the northern coast of the island [Fjellberg, 1997] and a part of the northern coast of Murchison Fjord in the southern part of the island [Coulson et al., 2011], a list of springtails of the island has increased to 40 species. Information on density of collembolans in different biotopes of the Nordaustlandet is not available.

This publication was prepared within the framework of our studies of soil microathroropods on birds and ornithogenic substrates on Svalbard [Lebedeva et al., 2006; Lebedeva \& Lebedev, 2008; Lebedeva, 2012; Lebedeva et al., 2012]. Its purpose is to analyze new material from the Arctic skua (Stercorarius parasiticus L.) habitat in the insufficiently studied part of the archipelago, which allows a better understanding of the distribution and biotopic preferences of collembolans above $80^{\circ} \mathrm{N}$.

\section{Material and methods}

The material was collected by first author 22.07. 2010 on the polar desert island of Nordaustlandet on Svalbard $\left(80^{\circ} 03^{\mathrm{N}} \mathrm{N}, 18^{\circ} 13^{\prime} \mathrm{E}\right)$ at a height of $9 \mathrm{~m}$ a.s.l. on the northern coast of the Murchison fjord in the western part of the island near the Kinnvika research station (Fig. 1).

Ornithogenic soil was collected with the vegetation at the breeding plot of Arctic skua pairs. Nesting habitat of this Arctic skua pair represented a seaside terrace, which was characterized by the presence of local wetland depressions and polygonal forms of microrelief (Fig. 2).
Plant communities were located in the central part of the polygons, covering $75 \%$ of their area. As shown in similar communities of coastal terraces on the coast of Rijpfjorden, lichens Ochrolechia spp., Lecidea spp., Placyntium spp., and Hepaticae Gymnomitrion corallioides, Cephalozia grimsulana, Anthelia juratzkana are the dominant group of plants in these communities. Vascular plants Luzula confusa, Papaver polare, Sagina intermedia, Cerastium alpinum, Draba alpina, Salix polaris, Stellaria crassifolia cover less than 1\% [Koroleva, 2007]. The soil was enriched with excrement and remains of the birds' food.

Sample volume was $1 \mathrm{dm}^{3}$. This sample was delivered to the laboratory of the Kola Science Centre research station of in Barentsburg on the same day, divided into two parts and placed on Berleze-Tullgren funnels for the extraction of invertebrates under an electric lamp $(60 \mathrm{~W})$ for 7 days. Microarthropods were stored in $70 \%$ ethanol before species identification. Collembola were identified by A.A. Taskaeva.

\section{Results and discussion}

We recorded 183 springtails from 8 species. In the sample from the Arctic skua habitat, their density in the soil and vegetation cover was 18,300 ind $\times \mathrm{m}^{\prime 2}$. The list of species, information about their distribution, habitat preferences according to published data [Summerhayes \& Elton, 1928; Babenko \& Bulavintsev, 1997; Fjellberg, 1997; Bulavintsev \& Babenko, 1998; Babenko \& Fjellberg, 2006; Coulson et al., 2011], and relative

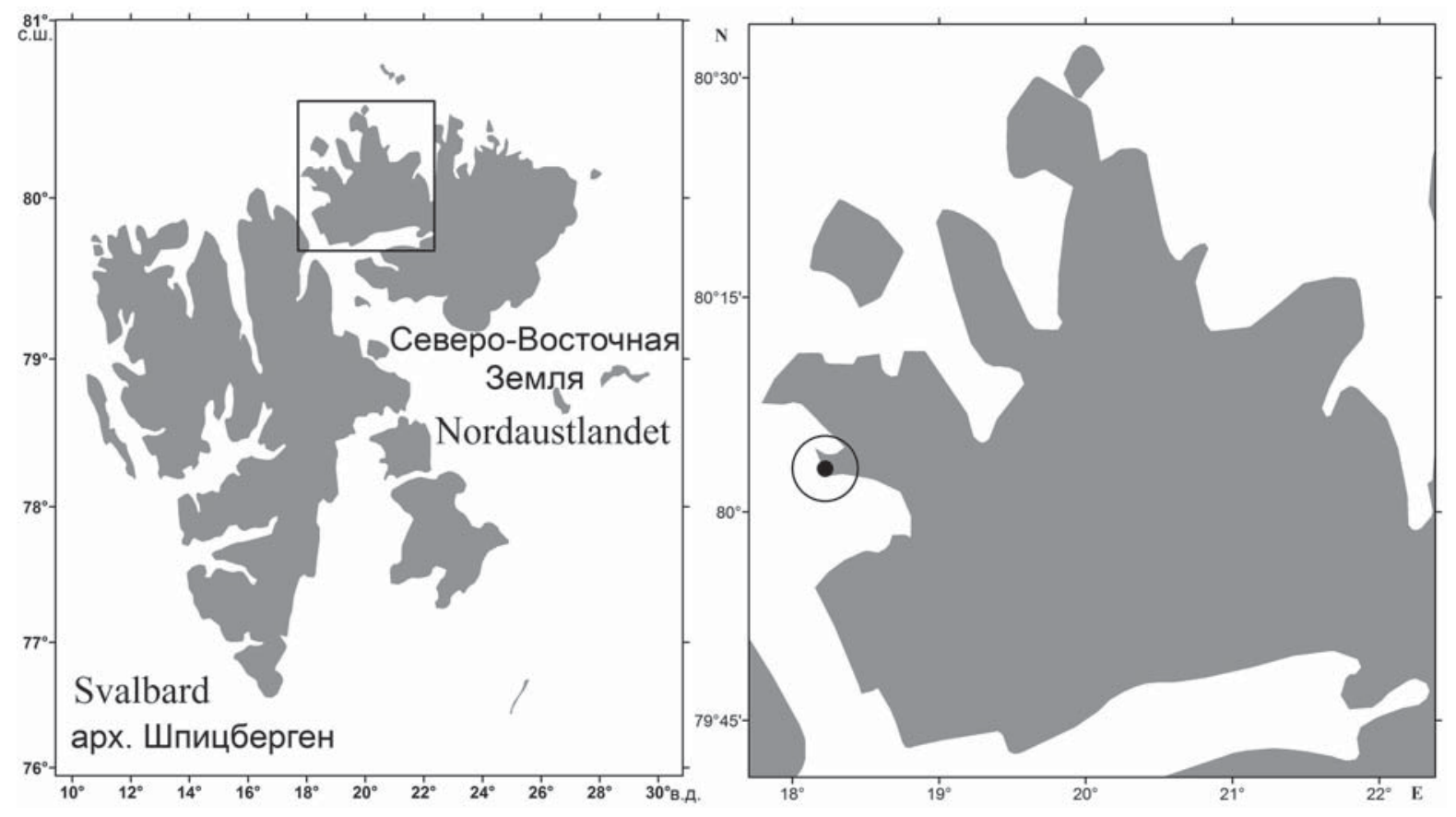

Fig. 1. Map of location of study area: Svalbard shown on the left, the sampling point in the Arctic skua habitat on the the Nordaustlandet island shown on the right.

Рис. 1. Местоположение района исследования: арх. Шпицберген показан слева, точка отбора пробы в местообитании короткохвостого поморника на о-ве Северо-Восточная Земля показана справа. 
abundance (authors' data) in the soil samples are shown in Table.

Any information on the abundance of collembolans (except for the relative occurrence of various types in samples from different habitats [Fjellberg, 1997]) in published data from Nordaustlandet is not available. However, it has been shown that in more Southern areas of Spitsbergen, the density of springtails varies widely, and is significantly higher than we recorded in a sample from Arctic skua habitat. Thus, in Ny-Ålesund $\left(78^{\circ} \mathrm{N}\right)$, the density of collembolans was $21,000-38,000$ ind. $\times \mathrm{m}^{-2}$ in lichen tundra, 243,000 and 268,000 ind. $\times \mathrm{m}^{-2}$ in moss and grass tundra, respectively [Bengtson et al., 1974]. On the bird cliffs in the Horsund area $\left(77^{\circ} \mathrm{N}\right)$ the Collembola density ranged from 670,000 to 1500,000 ind. $\times \mathrm{m}^{-2}$, about 8-20 times higher than the number in moss-lichen and coastal polygon tundra) and two times higher than in wet moss tundra [Byzova et al., 1995].

Of course our fragmentary data on the relative abundance collembolans in a sample of the Arctic skua habitat breeding in a polygonal arctic tundra do not provide a full view of their distribution in the biotope due to its mosaic form. However, data on the specific abundance for this group of invertebrates from Nordaustlandet are available for the first time.
So far 40 species collembolans are reliably recorded on Nordaustlandet [Summerhayes \& Elton, 1928; Fjellberg, 1997; Coulson et al., 2011, our fees], ie $79 \%$ of the whole fauna, known for the Svalbard archipelago. A similar level of diversity is typical for arctic tundra faunas of the Novaya Zemlya archipelago (42 species), Elsmir (42), and Devon (37) Islands of Canadian Arctic Archipelago. Faunas of springtails of polar desert the Canadian Arctic archipelago (Ellef Ringnes Island), Franz Josef Land archipelago have a low diversity (13 and 14 species, respectively). The exception is the diversity of collembolans of polar desert of Severnaya Zemlya archipelago, where there are 36 species [Babenko, 2010]. In general, species richness of collembolans of the investigated area is high enough, but we can assume that it is not fully revealed. This is due to inaccessibility of the area as a whole and low amount of research on different habitats. The Eastern part of the island remains unexplored.

The highest recorded species diversity (11 species) was from the Murchison Fjord area under bird cliffs with characteristic lush vegetation on relatively powerful humidified soils [Fjellberg, 1997]. Most of the species found by us in the same area in the Arctic skua habitat belong to a group of arctic and polyzonal species. Thus,

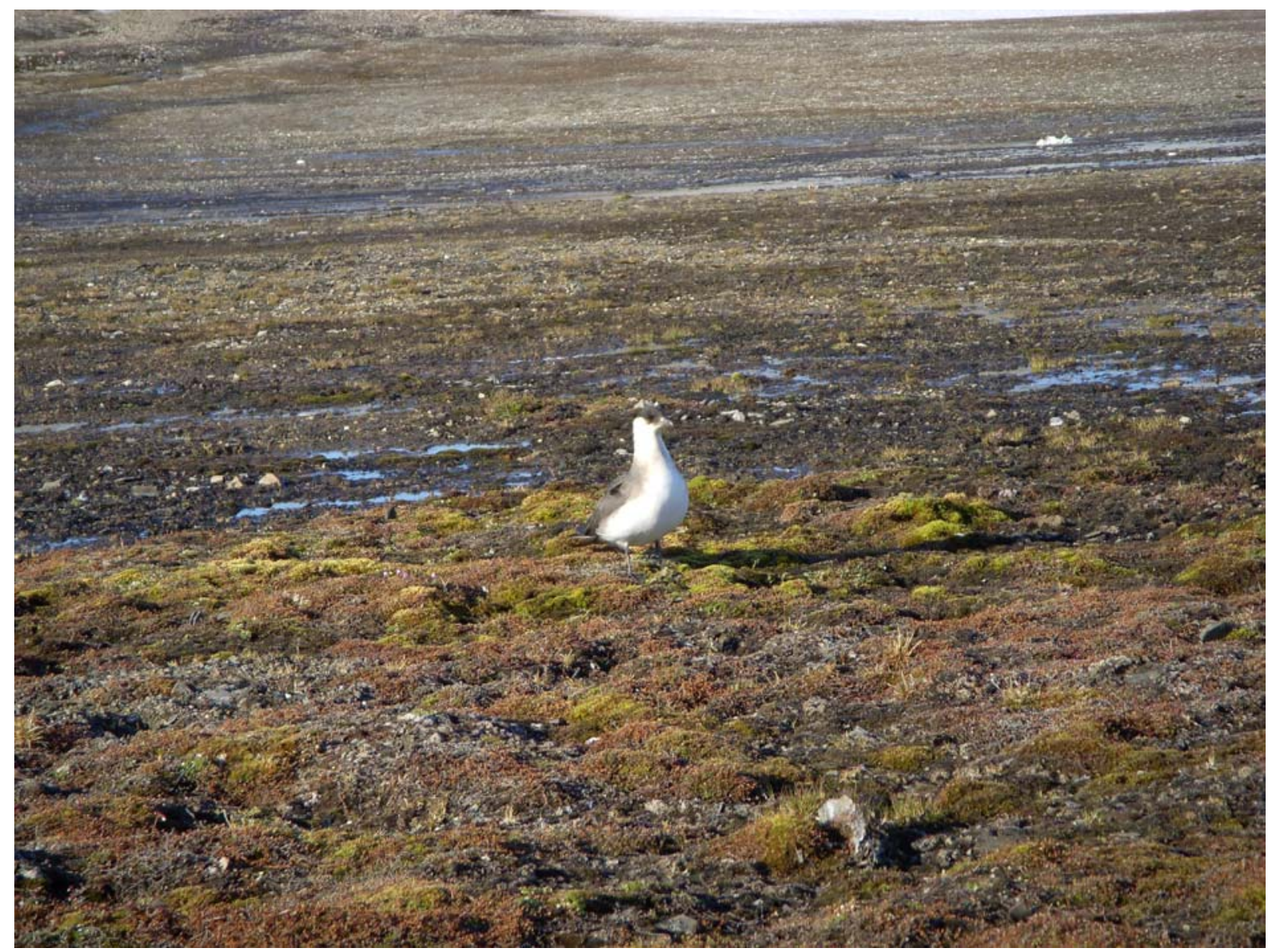

Fig. 2. The Arctic skua habitat on the Nordaustlandet (Svalbard archipelago). Photo by N.V. Lebedeva.

Рис. 2. Местообитание корткохвостого поморника на Северо-Восточной Земле (арх. Шпицберген). Фото Н.В. Лебедевой. 
N.V. Lebedeva \& A.A. Taskaeva

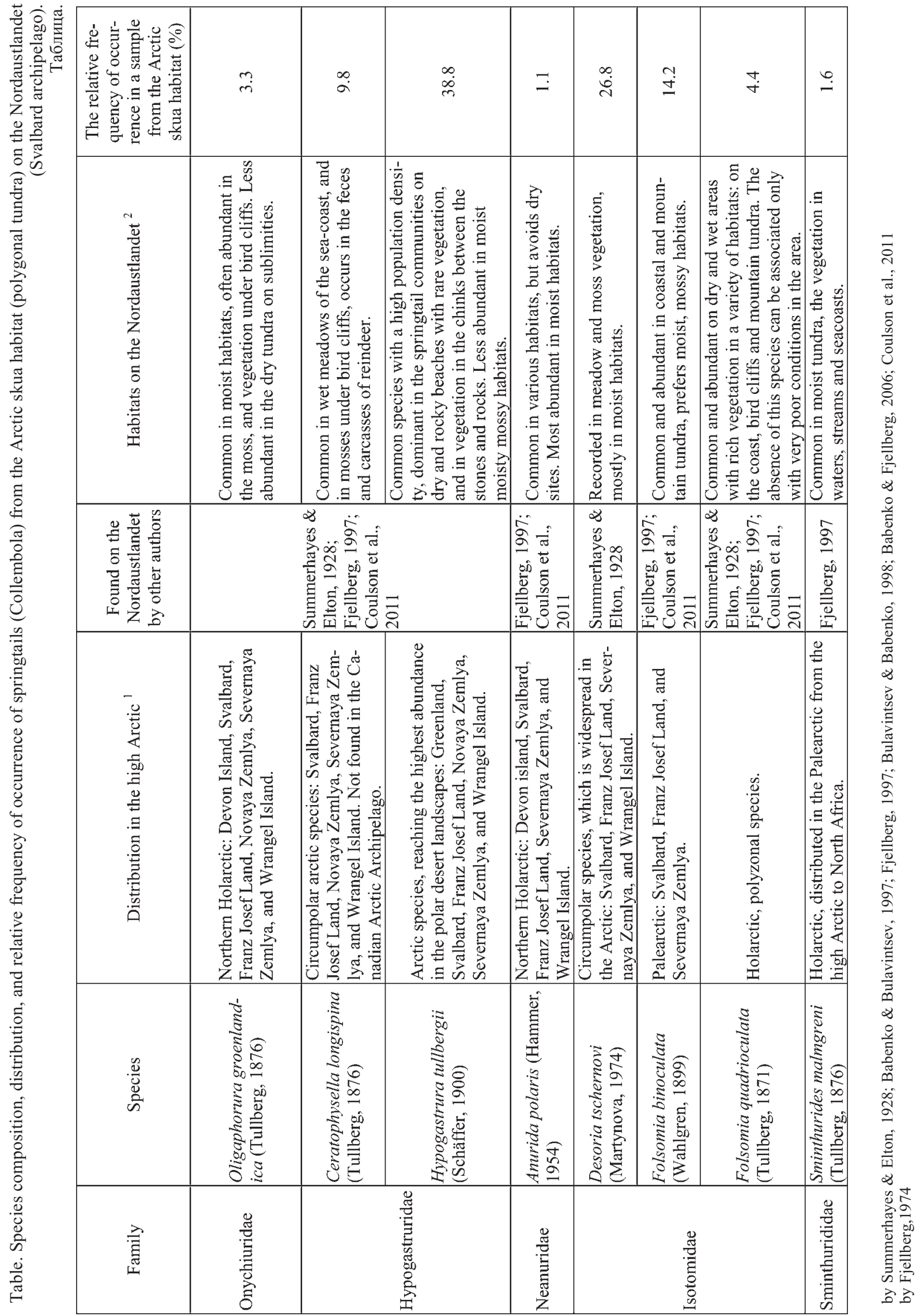


five of the eight species (Oligaphorura groenlandica, Ceratophysella longispina, Hypogastrura tullbergii, Anurida polaris, Folsomia binoculata) can be considered as true arctic species, two species (Folsomia quadrioculata, Sminthurides malmgreni) as polyzonal, and one (Desoria tschernovi) of them as hemiarctic species, ie is most abundant in the typical tundra subzone.

The diversity of collembolans in the Arctic skua habitat on Nordaustlandet is relatively high and can be compared to the diversity of springtails under bird cliffs. $H$. tullbergii and $D$. tshernovi dominated in the sample analyzed by the authors. The new data supplement the very limited information about the springtail communities in different habitats of poorly-studied areas in the Arctic.

ACKNOWLEDGMENTS. N.A. Konstantinova had inestimable help in collecting the material in the Nordaustlandet island (Svalbard archipelago). Field study on Svalbard was supported in 2010 by a project from the Russian Arctic Coal Mine Company, executed by the Murmansk Marine Biological Institute. The authors are grateful to A.B. Babenko for help in identifying some species of Collembola, V.V. Saprygin for preparing figures, Juhani Hopkins for English correction. Publication prepared in the frame of the international project "AVIFauna (Avian Vectors of Invertebrate Faunas)" (The Norwegian Research Council, 196172/S30).

\section{References}

Babenko A.B. 2010. The Springtail (Hexapoda, Collembola) Fauna of Wrangel Island // Entomol. Rev. Vol.90. No.5. P. 571-584.

Babenko A.B., Bulavintsev V.I. 1997. [Springtails (Collembola) of eurasian polar deserts] // Zool. Zhurn. Vol.76. No.4. P.409-417 [in Russian, with English summary].
Babenko A., Fjellberg A. 2006. Collembola septentrionale. A catalogue of springtails of the Arctic regions. Moscow: KMK Scientific Press Ltd. 190 p.

Bengtson S.-A., Fjellberg A., Solhøy T. 1974. Abundance of tundra arthropods in Spitsbergen // Entomologica Scandinavica. Vol.5. P.137-142.

Bulavintsev V.I., Babenko A.B. 1998. [Collembola complexes of the Novaya Zemlya] // Novaya Zemlya. Priroda. Istoria. Arkheologia. Kultura. Trudi morskoi arcticheskoi komlexnoi ekspedicii (MAKE). Kniga 1. P.251-255 [in Russian].

Byzova J.B., Uvarov A.V., Petrova A.D. 1995. Seasonal changes in communities of soil invertebrates in tundra ecosystems of Hornsund, Spitsbergen // Polish Polar Research. Vols3-4. No.16. P.245-266.

Coulson S.J. 2007. The terrestrial and freshwater invertebrate fauna of the High Arctic archipelago of Svalbard// Zootaxa. Vol.1448. P.41-58.

Coulson S.J., Fjellberg A., Snazell R., Gwiazdowicz D.J., AvillaJiménez M.L. 2011. On the Collembola, Aranea and Gamasida from the Kinnvika region of Nordaustlandet, Svalbard // Geografiska Annaler. Series A. Physical Geography. Vol.93. P. 253-257.

Fjellberg A. 1997. Collembola from Nordaustlandet, Svalbard // Fauna Norvegica. Series B. Vol.44. P.71-75.

Koroleva N.E. 2007. Plant communities of the Reipfiord, Nordaustlandet (Spitsbergen archipelago) // Complex investigations of Spitsbergen nature. Issue 7. Apatity: CSC RAS Publ. P. 278-284.

Lebedeva N.V. 2012. Oribatid mites transported by birds to polar islands. A review // Berichte zur Polar- und Meeresforschung. Bd.640. S.152-161.

Lebedeva N.V., Lebedev V.D. 2008. Transport of oribatid mites to the polar areas by birds // M. Bertrand, S. Kreiter, A. Migeon, M. Navajas, M.-S. Tixier \& L. Vial (eds.). Integrative Acarology. EURAAC Publ. P.359-367.

Lebedeva N.V., Lebedev V.D., Melekhina E.N. 2006. New data of Oribatid mite (Oribatei) fauna of the Svalbard // Doklady Biological Sciences. Vol.407. P.182-186.

Lebedeva N.V., Melekhina E.N., Gwiazdowicz D.J. 2012. [New data on soil mites in the nests of the Glacous gull Hyperboreus L. on Svalbard] // Vestnik Yuzhnogo nauchnogo centra RAS. Vol.8. No.1. P.70-75 [in Russian, with English summary]. Summerhayes V.S., Elton C.S. 1928. Further contributions to the ecology of Spitsbergen // Journal of Ecology. Vol.16. P.193268 . 